\title{
Mechanical Prime Movers
}

Mechanical

Engineering Series

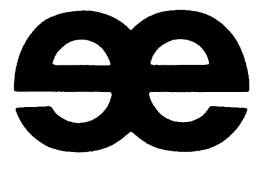

Macmillan

Engineering Evaluations 


\section{Mechanical}

Prime

Movers

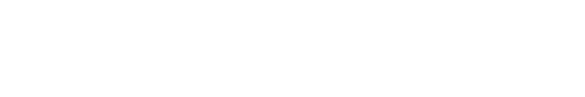

Edited by Peter C Bell BSc

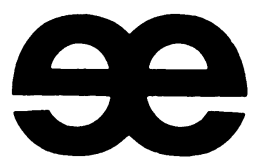

\section{Macmillan Engineering Evaluations}

Published by

The Macmillan Press Limited

Technical and Industrial Publishing Unit

Managing Editor William $F$ Waller

AMITPP AssIRefEng

Advertisement Representative Alan Kay

General Manager Barry Gibbs

The Macmillan Press Limited

Brunel Road Basingstoke Hampshire UK

Price $£ \mathbf{3 . 5 0}$

ISBN 978-1-349-01184-1 ISBN 978-1-349-01182-7 (eBook) DOI 10.1007/978-1-349-01182-7

(C) The Macmillan Press Limited 1971

Softcover reprint of the hardcover 1st edition 1971 978-0-333-12539-7

SBN 333125398 


\section{Foreword}

The mechanical prime movers discussed in this book are mainly those which convert the heat energy in conventional fossil fuels into useful sources of mechanical power. The conversion process takes place within the engine system (unlike the steam engine or steam turbine) using atmospheric air both as the working fluid and the source of oxygen for combustion. An exception is the closed cycle gas turbine (mentioned in chapter 8) for which an external heat source may be provided by conventional or nuclear fuels.

The spark-ignition engine is probably the best known because of its very wide use in cars and other road vehicles. However, chapter 1 discusses the types of s.i. engine that are used for industrial applications other than road transport. Large road transport vehicles and mobile off-highway equipment are increasingly important to industry; though the diesel engine (chapter 5) is the principal prime mover in this field, the gas turbine has considerable potential (chapter 9).

Diesel engines are manufactured in a wide range of sizes, and are discussed here in two groups: from the smallest units to about $400 \mathrm{~kW}$ (chapter 2) and the medium-large range (chapter 3). Although there is now no marked difference in basic design of diesels for industrial or marine use, there are particular characteristics that must be considered in the marine field (chapter 4).

From many years of experience and development, the reciprocating piston engine is still the most widely used, and most economical to build and operate for a mass market; however, rotary engines have specific advantages, and their use will increase. Derivatives of the aircraft gas turbine engine are used as large land and marine power units (chapter 7), while other gas turbines have been designed specifically for industrial applications (chapter 8). A relative newcomer is the rotary piston machine; the Wankel engine is currently being widely developed in spark- and compression-ignition forms (chapter 6).

The efficient use of prime movers depends on various ancillary systems: fuel supply, ignition systems, induction and exhaust (chapters $10,11,12$ ), and on correct lubrication and maintenance (chapters 14, 15). Efficiency and economy may be considerably affected by variations in operating parameters; some basic control functions and systems are discussed in chapter 13.

Engine designers and builders have to keep up with developments in design, materials, and techniques, in order to compete; a list of some makers of different types of engine is appended as a source of further information. 


\section{Contents}

\section{Spark Ignition Engines}

Automotive Gas Turbines

ENGINEERING GROUP

Technical Sales Department

Norton Villiers Limited

2

\section{Small Diesel Engines}

A J V JOSEPH CEng MIMechE

Chief Engineer, Research \& Development

Petters Limited

3

\section{Industrial Diesel Engines}

A J GLASSPOOLE MA CEng FIMechE

Group Engineer, Product Technology

English Electric Diesels Ltd

4

\section{Marine Diesel Engines}

D CASTLE CEng FIMechE

Engineering Manager

Crossley-Premier Engines Limited

5

Automotive Diesel Engines

W G WESTWELL CEng MIMechE

Forward Engineering Manager

Perkins Engines Company

6

\section{Rotary Piston Engines}

$P \vee$ MANTEUFFEL Dip/-Ing

Asst Director of Research

Audi NSU Auto Union AG

7

\section{Adapted Aero Gas Turbines}

W U SNELL CEng FIMechE FRAeS

Rolls-Royce (1971) Ltd

Industrial and Marine Division

8

\section{Industrial Gas Turbines}

P C BELL BSC MCIMM

with the co-operation of

Ruston Gas Turbines Limited

97
P C BELL BSC MCIMM

F W ARMSTRONG MSc(Eng) MIMechE AFRAeS

National Gas Turbine Establishment

10

\section{Fuel Systems}

P B BOSTOCK MIMechE AIAgrE CEng Diesel Engineer, Technical Services Branch BP Trading Limited

11

Ignition Systems

G E FARDON CEng MIMechE MIEE

Consultant

12

Induction and Exhaust

E A STOKES MBE CIHVE; D G CROSIER

Technical Adviser; Acoustics Engineer

Air Division, Vokes Limited

\section{3}

\section{Control Functions}

G E MUNNS BScEng CEng MIMechE

Head of Digital Control Research

National Gas Turbine Establishment

14

\section{Lubrication Principles}

A L MILLS BSc FRIC FInstPet

General Manager, Product Development

Burmah-Castrol Company

15

\section{Maintenance}

S D McDONALD MBE BSC

PA Management Consultants Ltd

Guide to Engine Makers

Glossary of Terms
169 